\title{
SPOSOBY INICJOWANIA I PODTRZYMYWANIA KONTAKTU ZE STUDENTAMI NA LEKCJI JEZYKA POLSKIEGO JAKO OBCEGO
}

\begin{abstract}
Słowa kluczowe: komunikacja na lekcji języka polskiego jako obcego (JPJO), komunikacja edukacyjna, dyskurs lekcyjny, lekcja JPJO, nauczanie JPJO, inicjowanie kontaktu ze studentem, podtrzymywanie kontaktu na lekcji

Streszczenie. Celem artykułu jest przedstawienie rejestru zachowań werbalnych (ustnych) lektorów, które zostały ukierunkowane na zainicjowanie kontaktu ze studentami, podtrzymanie uwagi oraz aktywizowanie uczestników zajęć w przestrzeni zinstytucjonalizowanej. Badano również wpływ tego rodzaju wypowiedzi lektorskich na sposób i jakość nauczania w zróżnicowanej etnicznie grupie. Analiza materiału badawczego, obejmującego dwanaście 90-minutowych nagrań (wraz z transkrypcjami) lekcji języka polskiego jako obcego (JPJO) przeprowadzonych w Studium Języka Polskiego dla Cudzoziemców Uniwersytetu Łódzkiego, pozwoliła na opracowanie rejestru typowych, najczęstszych sytuacji komunikacyjnych, w których dochodziło do interakcji lektora ze studentami, jak również na dostrzeżenie i usystematyzowanie powtarzających się elementów wspólnych tworzących schematy komunikacyjne. Zaprezentowane badania mają charakter językoznawczo-glottodydaktyczny, stanowią jednocześnie niewielką część rozważań nad komunikacja edukacyjna w klasie językowej, które zostały zainicjowane w 2010 roku na potrzeby rozprawy doktorskiej.
\end{abstract}

Właściwa, odpowiednio dostosowana do kontekstu oraz umiejętnie prowadzona komunikacja werbalna lektora na lekcji języka polskiego jako obcego (JPJO) wydaje się sprawą niezwykle ważną, mającą bezpośredni i nieoceniony wpływ na przebieg procesu nauczania, jego jakość, płynność, a także na stworzenie sprzyjających warunków nie tylko do uczenia się, ale i swobodnej wypowiedzi studentów czy nieskrępowanego wyrażania przez nich własnych poglądów. Niejednokrotnie to lektor wykonuje w rozmowie pierwszy krok, rozumiany nie tylko w sposób metaforyczny, ale także, odwołując się do U. Żydek-Bednarczuk, jako najmniejsza jednostka tekstu. Oznacza on zabranie głosu i wypowiedzenie kwestii przez part-

*kamila.kubacka@umed.lodz.pl, Uniwersytet Medyczny w Łodzi, Centrum Nauczania Języków Obcych, pl. Hallera 1, 90-647 Łódź. 
nera rozmowy. Po nim następuje bezpośrednio krok drugi, którym jest zmiana roli nadawczo-odbiorczej i przejęcie przez odbiorcę roli mówcy (Żydek-Bednarczuk 1994, s. 52-67). Każdy krok jest niezmiennie rozpoczynany incipitami, wśród których można wyróżnić: formuły pozdrowień, incipity emocjonalne, quasi-czasownikowe sygnały kontaktu, spójniki jako sygnały pełniące funkcję konatywną, połączenia różnych incipitów oraz zwroty adresatywne (Rachwałowa 1996, s. 131).

Mając na uwadze istotną rolę komunikacji na lekcji JPJO, a przede wszystkim sposób jej inicjowania przez uczącego, w niniejszym artykule skoncentrowano się na przedstawieniu określonego rejestru zachowań werbalnych (ustnych) lektorów na lekcji JPJO oraz wpływu (pozytywnego, jak i negatywnego) tego rodzaju wypowiedzi na sposób i jakość nauczania w niehomogenicznej grupie. Na potrzeby publikacji dokonano selekcji wybranych sposobów komunikacji nauczycieli JPJO, typowych dla środowiska uniwersyteckiego. Rejestr ten objął trzy podstawowe dla każdej lekcji sytuacje komunikacyjne: ukierunkowane na zainicjowanie kontaktu ze studentami oraz na aktywizowanie uczestników zajęć w przestrzeni zinstytucjonalizowanej, ukierunkowane na podtrzymanie uwagi, a także skoncentrowane na działaniach lektorskich mogących osłabiać motywację studentów do wypowiadania się na zajęciach. Sytuacje te zostały sklasyfikowane i opisane w dalszych podrozdziałach.

Podstawę badawczą stanowiły nagrania wraz z transkrypcjami 12 wybranych 90-minutowych lekcji JPJO, których uczestnikami byli studenci 7 grup wielonarodowościowych oraz 5 grup słowiańskich (w tym osoby polskiego pochodzenia) na różnym poziomie biegłości językowej (A2-C1). Badania miały miejsce w latach 2010-2014 w Studium Języka Polskiego dla Cudzoziemców UŁ. Zajęcia były prowadzone przez 12 lektorów (9 kobiet i 3 mężczyzn) w wieku 30-60 lat (staż pracy: 5-30 lat). Wszystkie wypowiedzi ustne nauczycieli i uczniów zostały zapisane $\mathrm{w}$ oryginalnym brzmieniu, bez ingerowania badacza $\mathrm{w}$ materiał empiryczny. Wykorzystane w analizie metody badawcze to głównie obserwacja nieuczestnicząca, analiza konwersacji i analiza dyskursu dydaktycznego.

\section{ZACHECANIE STUDENTÓW DO AKTYWNEGO UCZESTNICZENIA W LEKCJI JPJO}

Prowadzone w pierwszej dekadzie XXI w. badania dotyczące różnorodnych sposobów zachęcania studentów do wypowiadania się na zajęciach wykazały, że największy wpływ na aktywizowanie uczących się mają, zdaniem uczniów i nauczycieli, następujące czynniki: staranie o zainteresowanie zagadnieniem, nieprzerywanie wypowiedzi studentów, pochwały, uważne słuchanie ucznia przez nauczyciela czy brak krytyki ze strony uczącego (Mądry-Kupiec 2011, s. 99-108).

Analiza potwierdziła, iż na wzbudzenie zainteresowania wśród uczniów, a także zwiększenie ich motywacji i chęci zabierania głosu na lekcji duży wpływ ma nie tylko wybór tematyki zajęć, ale również dobór oraz atrakcyjność materia- 
łów dydaktycznych. Wielu nauczycieli poddanych badaniu dbało o urozmaicenie zajęć poprzez prezentowanie materiałów wizualnych (fotograficznych, filmowych) i audio. Niektórzy za istotne uznali także uatrakcyjnienie nawet ćwiczeń drylowych, stricte gramatycznych, w których, zamiast standardowych i przewidywalnych treści pojawiały się przykłady o zabarwieniu humorystycznym, np.:

[1] S: Gdyby twoja siostra nie była taka brzydka, ja oże-ożenił-ożeniłby...

$\mathrm{L}_{\mathrm{vI}}: \mathrm{m} \ldots \mathrm{Ja} \ldots$

S: Ożeniłbym się z nią.

Innym, częstym zabiegiem było wprowadzenie anegdoty. Umiejętnie wpleciona w tok lekcji miała za zadanie nie tylko skupić uwagę słuchaczy na zagadnieniu, do którego się odnosiła, ale przede wszystkim rozluźnić atmosferę panującą w klasie, np.:

[2] $\mathrm{L}_{\mathrm{III}}$ : A ten proces, jak się nazywa?

S: Komunikacja.

$\mathrm{L}_{\mathrm{III}}$ : Komunikacja, oczywiście. (...) To Laura nam opowiadała o Polańskim, ale gdyby przywołała nam na przykład Kieślowskiego, to by nam wtedy opowiedziała anegdotę. Dostał na egzaminie do szkoły filmowej, tutaj w Łodzi, takie pytanie: środki komunikacji międzyludzkiej. Co powiedział? Tramwaj, autobus. Zdał, bo komisja oczywiście wyczuła... [śmiech]. Dobrze, więc tutaj komunikatywność, czyli umiejętność porozumiewania się. Nie komunikacja, nie komunikat.

Należy jednak dodać, iż lektorzy opowiadający anegdoty prowadzili zajęcia w grupach o wysokim stopniu zaawansowania językowego. Nauczyciel poprzez żarty, niekiedy podbarwione dużą dozą ironii, miał także możliwość oceny zdolności językowych uczniów.

Powstaje jednak pytanie, w jaki sposób aktywizować studentów, którzy, pomimo uatrakcyjnienia zajęć przez lektora, nie chcą brać czynnego udziału w zajęciach? Kwestią nadrzędną jest przede wszystkim nawiązanie bezpośredniego kontaktu z uczestnikami zajęć. Może ono przebiegać na wiele sposobów, np. poprzez stosowanie przez nauczyciela pytań rozpoczynających się zaimkiem pytajnym: kto?, zawierających prośbę o zabranie głosu skierowaną do zbiorowości, np.:

[3] $\mathrm{L}_{\mathrm{VIII}}$ : Kto jeszcze chciałby? (A) Kto ma inaczej? (B) Cisza. Nie ma się czego bać! Proszę bardzo, kto jeszcze przeczyta swoja notatkę? (C) Nie zrobiliście? (D)

S: Zrobiliśmy.

$\mathrm{L}_{\mathrm{VIII}}$ : No to... czego się tu wstydzić? Bać? (E) Proszę bardzo. Kto spróbuje? Mam wskazać palcem? (F)

S: Ja mogę.

$\mathrm{L}_{\mathrm{VIII}}$ : Proszę.

W przykładzie [3] lektor, wypowiadając to samo pytanie, jednak w różnych wariantach (fragmenty A, B, C), stara się zaktywizować grupę. Obok wspo- 
mnianych, wystąpiły także pytania wyrażające wątpliwości nauczyciela odnoszące się do wykonania powierzonego zadania (fragment D), a także wypowiedzi świadczące o pewnej empatii uczącego (fragment E) i próbie postawienia się w roli ucznia. Dość ogólne i mało skuteczne komunikacyjnie wydawały się tu zdania: Proszę! (Proszę bardzo), które, pomimo wielokrotnego powtarzania przez nauczyciela, nie przyniosły pożądanego efektu. Prośba była wówczas wzmacniana innymi zabiegami słownymi o zdecydowanie bardziej kategorycznym wydźwięku, co w konsekwencji przypominało raczej groźbę. Tak sformułowane zdania występowały najczęściej jako elementy wieńczące wypowiedź lektora (fragment $\mathbf{F}$ ).

Bardziej praktyczne i skuteczne było przechodzenie w wystąpieniu nauczyciela od uogólnienia do szczegółu, np.:

[4] $\mathrm{L}_{\mathrm{III}}$ : A może by tamci, których nie było wczoraj, troszeczkę głos zabrali? Wszyscy śpią, ja rozumiem, pierwsza lekcja, ale słoneczko rozbudza.

[5] $\mathrm{L}_{\mathrm{VIII}}$ : Proszę! Kto zaczyna? Proszę, może po kolei (A).

[6] $\mathrm{L}_{\mathrm{I}}$ : Kto nam tu czyta? Kto tu dzisiaj mało mówił? (A) O! Może pani Olena! (B)

W przykładzie [4] nauczyciel zawęża pytanie do wybranej grupy studentów, w kolejnym ogranicza adresatów do jednej osoby (fragment A), uściślając przy tym przebieg dalszego przejmowania roli mówcy. Zarówno jeden, jak i drugi sposób nie wydaje się właściwy. Tak ogólnikowe pytania skierowane do zbiorowości sprawiają, że zrzucona zostaje odpowiedzialność poszczególnych osób za udział w lekcji. W konsekwencji obowiązek ten wypełniają albo cały czas te same osoby, które nie wymagają dodatkowej zachęty do podjęcia działań językowych, albo prośba nauczyciela pozostaje bez odpowiedzi. Studenci są wówczas bierni i nie podejmują inicjatywy. Co więcej, pytanie uczniów po kolei sprawia, iż uczący się dość szybko ulegają dekoncentracji, a sam przebieg lekcji jest dla nich przewidywalny i oczywisty, np.:

[7] $\mathrm{L}_{\mathrm{II}}$ : Samir. Samir czy Diana? Samir.

S: Jedenaste?

$\mathrm{L}_{\mathrm{II}}$ : Dwanaście Samir - pytanie po kolei - student się zgubił, nie uważał.

Proszenie o odpowiedź studentów dokonywane w nieprzewidywalnej kolejności (Komorowska 2001, s. 71) jest znacznie bardziej efektywne niż odpytywanie ich po kolei. Elementem istotnym dla podtrzymania kontaktu z uczestnikami zajęć jest przede wszystkim niepewność, co do tego, kto w danym momencie będzie zabierał głos na lekcji. Służą temu różne techniki, np.: proszenie konkretnego studenta o odpowiedź dopiero po wypowiedzeniu pytania lub polecenia, unikanie pytania po kolei oraz pytania „sąsiad-sąsiad” w dialogach, a także absorbowanie słuchaczy siedzących w bocznych ławkach, często pomijanych przez prowadzących zajęcia. Najbardziej stosowny wydaje się przykład [6]: pierwsza część wy- 
powiedzi lektora przykuwa uwagę i aktywizuje grupę (fragment A), a kolejna wskazuje na konkretnego studenta (fragment B).

Większość lektorów, zwracając się do uczniów, używała ich imion opatrzonych zwrotami grzecznościowymi: pani/pan lub też imion czy przezwisk wplecionych w konstrukcję 2. os. 1. poj., np.:

[8] $\mathrm{L}_{\mathrm{II}}$ : A teraz $\underline{\text { Altancece, }}$ ty robisz to zdanie.

[9] $\mathrm{L}_{\mathrm{I}}$ : Dobrze, że pan Andrzej jest tutaj, yyy...dzisiaj nie podpiera się i nie śpi, dzisiaj jest czujny (A).

[10] $\mathrm{L}_{\mathrm{II}}$ : I jeszcze raz Altancece, już teraz ładnie, jak Polka (B).

Ponadto, w przykładach [9] i [10] oprócz bezpośredniego zwrotu do wybranych studentów, nauczyciel przekazywał także inne intencje, m.in.: nieco ironiczną pochwałę (fragment A), polecenie czy życzenie (fragment $\mathbf{B}$ ).

Innym sposobem było przechodzenie od szczegółu do ogółu w bezpośrednich zwrotach do adresata, wśród których można było wyróżnić trzy najbardziej charakterystyczne sytuacje komunikacyjne, np.:

[11] S: Gdyby...eee...Weronika była lekarką, nie zrobiłaby zastrzyk...

$\mathrm{L}_{\mathrm{II}}$ : Nie zrobiłaby zastrzyku! [śmiech] To bardzo dobrą lekarką byłaby Weronika! Weronika nie mogłaby być lekarką, bo nie zrobiłaby zastrzyku. Tak?

S2: Nie lubię!

$\mathrm{L}_{\mathrm{II}}$ : Nie lubisz. [śmiech] Yyy...Weronika, ty z kim rozmawiałaś? I jakie masz zdania?

[12] $\mathrm{L}_{\mathrm{II}}$ : Pani, pani, pani... Diana zaczyna czytać ten tekst, tylko: Gdybyście dobrze znali język polski, do Samira i Filipa mówisz. (...) I teraz Florance mówisz do Tengisa i Samira.

[13] $\mathrm{L}_{\mathrm{X}}$ : Czyli chcesz powiedzieć, że spotkanie Barbary i Jarka...

S: ...spotkanie Barbary i Jarka były krótkie, krótkie i przy-przypadkowe.

(...)

$\mathrm{L}_{\mathrm{x}}$ : Zgadzacie się? Wszystkie były krótkie i przypadkowe?

W przykładzie [11] nauczyciel poprosił o zabranie głosu konkretną osobą, która w swoją wypowiedź wplotła imię siedzącej obok koleżanki, co umiejętnie wykorzystał lektor, nawiązując z nią kontakt. Dialog [12] ilustruje z kolei, w jaki sposób można zaangażować w proces komunikacyjny innych uczestników zajęć. Lektor wyznacza konkretnego studenta do przeczytania tekstu, a następnie, poprzez odpowiednie polecenie, egzekwuje zamianę pojedynczego adresata na grupę odbiorców, będących do tej chwili biernymi uczestnikami zajęć.

Przykład [13] ukazuje przejście od jednej osoby zaangażowanej w proces komunikacyjny do wszystkich uczestników zajęć. Można zatem zaobserwować naturalną przemianę dialogu w polilog.

Częstym zabiegiem stosowanym przez uczących na zachęcenie studentów do mówienia na lekcji było używanie pytań pedagogicznych. W terminologii dydak- 
tycznej pojęcie to funkcjonuje jako pytanie zadawane „nie w celu dowiedzenia się czegoś nowego, bo pytający zna na nie odpowiedź, lecz w celu sprawdzenia, na ile uczeń potrafi tę odpowiedź przedstawić w niezmienionej formie" (Mądry-Kupiec 2011, s. 98). Wypowiedzenia tego typu pojawiały się w znaczącej liczbie podczas zajęć języka polskiego jako inicjatory najczęściej krótkiej wymiany zdań, której celem nadrzędnym była nie rozmowa, a wyjaśnienie danego pojęcia czy zjawiska, np.:

[14] $\mathrm{L}_{\mathrm{III}}$ : Proszę mi powiedzieć, jaka jest różnica pomiędzy uśmiechnięty, a śmieszny? Śmiejący się?

[15] $\mathrm{L}_{\mathrm{VII}}$ : Dobrze, rozumiemy florę? I faunę? Jak rozumiemy? Flora, co to jest, a co jest fauna?

Typowo pedagogiczne zdają się być również pytania typu:

[16] $\mathrm{L}_{\mathrm{III}}$ : A czy znacie z tym słowem związane jeszcze inne rzeczowniki?

[17] $\mathrm{L}_{\mathrm{IV}}$ : Państwo mają jakąś inną propozycję?

mające na celu uzyskanie nie jednej, konkretnej odpowiedzi, a całego zbioru różnych przykładów i wariantów. Badacze skłaniają się do określenia takich wypowiedzeń pytaniami niepedagogicznymi, pozornymi, zamykającymi i pozbawionymi sensu. Nauczyciel odpytuje studentów, sprawdza ich stan wiedzy, a także zgodność odpowiedzi z przekazywanym materiałem językowym (Mądry-Kupiec 2011, s. 98). Mimo iż pytania tego rodzaju nie powodują rozwijania sprawności mówienia, nie sposób jednak odmówić im przydatności, szczególnie w początkowym etapie nauczania języka obcego.

W bezpośredniej korelacji z omawianą grupą pytań pozostają te, które zawierają modulant jeszcze. Najczęściej pojawiały się w wypowiedziach aktywizujących, których celem było uzyskanie od uczących się jak największej liczby odpowiedzi na dany temat, np.:

[18] $\mathrm{L}_{\mathrm{I}}$ : No i co jeszcze tutaj mamy?

[19] $\mathrm{L}_{\mathrm{I}}$ : Dobrze. Czy jeszcze coś o tej rodzinie możemy powiedzieć? (A) (...) $\underline{\text { Ja oczywiście }}$ jestem w bardzo uprzywilejowanej, w stosunku do was, sytuacji, bo ja ten film widziałam ¡uż wiele razy. Natomiast wy widzieliście jeden raz, prawda? Obejrzał ktoś po raz drugi, żeby... no...lepiej zrozumieć? Nie. W zwiạzku z tym wiele szczegółów na pewno wam po tym jednorazowym obejrzeniu umknęło.

Przykład [19] oprócz charakterystycznego pytania (fragment A) zawiera pewnego rodzaju odpowiedź oraz dość obszerne objaśnienie, jakby lektor sam zdecydował się wytłumaczyć studentów z niedostatecznej i mało wnikliwej analizy filmu.

Wypowiedzenia zawierające wyraz jeszcze pojawiały się także, gdy lektor oczekiwał podania przykładów do omawianego zagadnienia. Co ciekawe, zdarzało się, iż komunikaty te poprzedzone były charakterystycznym dla dyskursu lekcyjnego pytaniem: Czy to wszystko?, np.: 
[20] $\mathrm{L}_{\mathrm{II}}$ : Dobrze, już wszystko? Nie ma więcej problemów w akademiku? (...) Czego jeszcze nie ma?

W opozycji do pytań pedagogicznych pozostawały pytania o opinię, które lektor zadawał $\mathrm{w}$ celu uzupełnienia faktycznej luki informacyjnej w treści rozmowy (zob. Komorowska 2001, s. 59). Celem takiej wymiany komunikacyjnej było poinformowanie rozmówcy o stanie emocjonalnym nadawcy lub jego prywatnych sądach na wybrany temat.

Do pytań o opinię należały zarówno te o charakterze ogólnym, np.:

[21] $\mathrm{L}_{\mathrm{I}}$ : Co sądzicie o takim systemie? (...) Jaką macie opinię? Jakie wnioski wyciągnęliście po, po obejrzeniu tego filmu?

[22] $\mathrm{L}_{\mathrm{IV}}$ : Dobrze, czy myślą państwo, że sportowiec... musi być dobrze zbudowany, musi być wysoki, musi mieć dużo mięśni? Bo wczoraj mówiliśmy o cechach, o charakterze, jaki powinien być sportowiec. Państwo mówili, że musi być energiczny, aktywny, wytrzymały, musi mieć silną wolę. A jeśli chodzi o fizyczny wygląd, budowę ciała, jaki musi być?

jak i nieco bardziej doprecyzowane, skupiające się na jednej kwestii podlegającej ocenie, np.:

[23] $\mathrm{L}_{\mathrm{III}}$ : To znaczy, że uważasz, że jeżeli ktoś żartuje, to nie wywołuje respektu?

[24] $\mathrm{L}_{\mathrm{III}}$ : Czy uważacie, że [lekarz] powinien być serdeczny?

Należy zwrócić uwagę, iż w treści przytoczonych wypowiedzeń pytających zawierały się charakterystyczne dla tej grupy czasowniki i zwroty, takie jak: $s a$ dzić, myśleć, uważać, mieć opinię itp.

Obok typowych pytań o sądy i opinie sporadycznie wystąpiły takie, których forma, jak i treść, wskazywały na wysoki poziom zaawansowania językowego słuchaczy, np.:

[25] $\mathrm{L}_{\mathrm{III}}$ : To znaczy, Władek, dopuszczasz inne możliwości?

[26] $\mathrm{L}_{\mathrm{I}}$ : Jesteśmy skłonni przyjąć takie wyjaśnienie? Czemu ściągnął na siebie karę za czyn, do którego poczuwał się winny?

a także takie, które łączyły w sobie elementy pytania retorycznego, jak i wyraźną ironię, np.:

[27] $\mathrm{L}_{\mathrm{III}}$ : No jasne, słuchajcie, czy wy znacie zawód, gdzie nie wymaga się od człowieka dobrego wykształcenia? Czy inżynier może być idiotą?

Do wypowiedzi o charakterze aktywizującym zakwalifikować można także wypowiedzenia łączące cechy pytania o opinię oraz negacji, np.:

[28] $\mathrm{L}_{\mathrm{III}}$ : No słucham, słucham grupę, bo ja się nie zgadzam z Laurą absolutnie! Proszę mi powiedzieć, dlaczego. Jak myślicie, dlaczego się nie zgadzam? 
Nauczyciel poprzez zaprzeczenie mobilizuje grupę do wnikliwszej analizy wypowiedzi ich koleżanki, a także do dokonania rewizji i oceny jej wystąpienia. Zastrzegł przy tym na wstępie, że on sam nie zgadza się z zasłyszaną informacją, co zainicjowało poszukiwanie przyczyn jego dezaprobaty, a zarazem dalszą dyskusję w klasie.

Podobny zabieg został zastosowany w przykładzie [29], w którym wyraźnie zaznaczyła się rola nauczyciela, umiejętnie kierującego dyskusją, w sposób umożliwiający studentom swobodę wypowiedzi. Wywołało to interesującą wymianę zdań:

[29] $\mathrm{L}_{\mathrm{XI}}$ : Dobrze, proszę państwa, Camillo, czy podoba się panu Łódź? Uwaga, ogłaszam, ja bardzo lubię Łódź! [śmiech]. Nie, nie, nie, ja lubię Łódź, ale ja jestem obiektywny.

S: [niezrozumialy fragment]...Warszawie, Kraków, tam są yyy...bardzo yyy... rozwiniętych, ale Łódź...trochę brudne...nie jest bardzo atrakcyjne. Kraków albo Warszawa są dobre.

$\mathrm{L}_{\mathrm{XI}}$ : No dobrze, kto nie zgadza się z panem Camillo? Wszyscy się zgadzają!

S: Nie, ja nie zgadzam się.

$\mathrm{L}_{\mathrm{XI}}$ : Nie zgadza się pan, dlaczego?

S: Bo, wie pan, że Łódź jest najtańszym miastem w Polsze, w Polsce, jak ja słuchałem z kolegów, z koleżanek...

Uczniowie byli otwarci, w sposób nieskrępowany mówili o swoich upodobaniach, nie bali się także pozostawać w opozycji do opinii lektora, właściwie argumentując swoje wybory. Warto także zwrócić uwagę, iż pomimo zachowania oficjalności lektora (zwroty grzecznościowe: pan, państwo) w stosunku do uczestników zajęć, na lekcji panowała pozytywna, dość swobodna i sprzyjająca komunikacji, atmosfera.

\section{PODTRZYMYWANIE KONTAKTU}

Drugą grupę wypowiedzi lektorów stanowią takie, których nadrzędną intencją było podtrzymanie uwagi rozmówców na omawianym zagadnieniu, szczególnie po dłuższych partiach monologowych nauczyciela. Ze względu na funkcje komunikacyjne w nich zawarte, dominująca w stosunku do innych była funkcja fatyczna.

Do wypowiedzeń tych należały:

- pytania o zgodę noszące znamiona pytań retorycznych, np.:

[30] L III: Ale każdy lekarz powinien umieć postawić dobrą diagnozę, przeprowadzić terapię, prawda?, 
- pytania o zrozumienie przekazywanych treści, wśród których trzeba wymienić wypowiedzenia pytające, zawierające czasownik rozumieć (zrozumieć) w: 1 os. 1. mn., 2. os. 1. poj. i mn. czy zwrotach grzecznościowych ze słowami: pan/pani/państwo, a także w formie przymiotnika, np.:

[31] L L : Rozumiemy?

[32] $\mathrm{L}_{\mathrm{II}}$ : Samir, rozumiesz?

S: Tak.

[33] $\mathrm{L}_{\mathrm{II}}$ : Rozumiecie to zdanie?

[34] $\mathrm{L}_{\mathrm{IV}}$ : A teraz wszystko pan już rozumie?

[35] $\mathrm{L}_{\mathrm{II}}$ : Rozumieją państwo?

[36] $\mathrm{L}_{\mathrm{VIII}}$ : Dobrze, czy tu są jakieś słowa niezrozumiałe $\mathrm{w}$ tym fragmencie tekstu? Coś mamy wyjaśnić?

również z pytaniem poprzedzającym: Jasne?, np.:

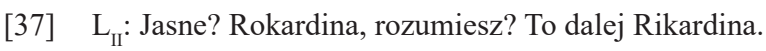

Niekiedy wypowiedzenia te wplecione były w nieco dłuższe partie dialogowe, $\mathrm{np}$.:

[38] $\mathrm{L}_{\mathrm{II}}$ : Czy wszystko jest jasne?

S: Tak.

$\mathrm{L}_{\text {II }}$ : Czy państwo rozumieją? Czy są pytania? Naomi? Rozumiesz?

S: Tak...trochę.

$\mathrm{L}_{\mathrm{II}}$ : Tak sobie? Tak? Potem po lekcji ci wytłumaczę, jeżeli nie będziesz rozumiała. Gdybyś nie rozumiała, to ci wyttumaczę.

Innymi wypowiedzeniami o podobnym charakterze były krótkie, pozbawione czasownika, pytania, np.:

[39] $\mathrm{L}_{\mathrm{II}}:$ Tak, jasne? Kirin?

[40] $\mathrm{L}_{\text {III: }}: \mathrm{W}$ porząidku?

stojące w opozycji do dłuższych, rozstrzygających lub odwołujących się do wiedzy, bądź też niewiedzy słuchaczy, np.:

[41] $\mathrm{L}_{\mathrm{III}}$ : Nie ma takiej osoby, która nie wie, czym zajmuje się logopeda? Nie ma?

Osobliwym pytaniem o zrozumienie omawianych treści, było wypowiedzenie zawierające czasownik: czuć:

[42] $\mathrm{L}_{\mathrm{v}}$ : Czujecie to?

odnoszące się do objaśnionego wcześniej pojęcia. 
- nawiązania werbalne (z użyciem czasowników) pojawiające się: przed podjęciem rozmowy jako element obudowujący wypowiedź oraz przydający jej element ciekawostki, a także zapowiadający dłuższy mono$\log , \mathrm{np}$. :

[43] S: I nie, nie rozumiem, dlaczego ludzie nie... mmm...buduje, budują nowych budynków w nowym stylu.

$\mathrm{L}_{\mathrm{xI}}$ : Już tłumaczę. Budują w kilku miejscach. Dwa problemy państwu wytłumaczę, dlaczego te domy, na przykład na Pomorskiej (...), a nawet niektóre na Piotrkowskiej, jedne domy na Piotrkowskiej są ładne, pomalowane, a inne są brudne i zniszczone.

również przed członem głównym wypowiedzi, np.:

[44] $\mathrm{L}_{\mathrm{III}}$ : Tak, wczoraj napisaliśmy dla lekarza (...), Władek podrzucił przymiotnik silny. Pamiętacie? I ja mówiłam, że lekarz nie musi być silny, ale musi być wytrzymały, bo jeżeli ma stać przy stole operacyjnym przez na przykład siedem godzin (...)?

lub też jako zwieńczające ją podsumowanie:

[45] $\mathrm{L}_{\mathrm{III}}$ : Jeżeli pielęgniarka naleje coś innego do kroplówki, czy poda inne lekarstwo, wyobrażacie sobie? Tak?

- nawiązania nominalne (z użyciem rzeczowników lub innych form imiennych) będące najczęściej powieleniem wypowiedzi wcześniej zasłyszanej, np.:

[46] $\mathrm{L}_{\mathrm{VIII}}$ : Dobrze, dziękuję. Kitel?

S: Fartuch.

$\mathrm{L}_{\mathrm{VIII}}:$ Fartuch, dobrze. Inaczej fartuch, a smoking i frak, to są rodzaje marynarek.

Oprócz powyższych, pojawiały się również sytuacje komunikacyjne, w których nauczyciel nie ograniczał się wyłącznie do podtrzymania kontaktu z uczącymi się, a przejmując rolę mówcy, umiejętnie sterował wcześniejszą wypowiedzią studenta, wykorzystując ją na potrzeby własnych wywodów, np.:

[47] $\mathrm{L}_{\mathrm{VIII}}:(\ldots)$ Następne określenie (...)

S: Proszek.

$\mathrm{L}_{\mathrm{VIII}}$ : Trochę to jest potoczne - proch. Wezmę procha, tak? [śmiech] Ale to jest określenie niemedyczne. Będziecie studiować medycynę, to nie powiecie: niech pan sobie weźmie procha [śmiech]. Proszę pana, jedna tabletka dziennie, jedna drażetka, jedna pastylka, tak? To są synonimy.

lub też na potrzeby dalszej rozmowy. Prowadzący wypytywał wówczas studentów o szczegóły ich wystąpienia w celu uzyskania interesujących go informacji, np.:

[48] $\mathrm{L}_{\mathrm{IX}}$ : Zaawansowana grupa, ja was pochwaliłam! A uczciwy to kulturalny! A państwo są uczciwi? 
[48] S: W poszczególnych przypadkach...

cd. $\mathrm{L}_{\mathrm{IX}}:$ A jak bardzo poszczególnych? Bo to coraz ciekawsze jest!

S: Kiedy nam to jest...wygodne. Kiedy od tego zależy...zależą...no kiedy trzeba coś tam, coś ukryć, to można nie być uczciwym, a kiedy jest wszystko okej, to można być uczciwym.

oraz form, np.:

[49] S: Oni, oni (...) tak, i robili coś takiego z marmurem i z octem...

$\mathrm{L}_{\mathrm{VIII}}$ : Mieszaninę, tak?

S: Tak. I...dawali no...pacjentu*.

$\mathrm{L}_{\mathrm{VIII}}$ : Komu dawali?

S: Ludziom chorym.

$\mathrm{L}_{\mathrm{VIII}}$ : Aaaa! Jak on wybrnạł! Ja chciałam usłyszeć pacjentów w celowniku. Komu dawali?

S: Pacjentom.

$\mathrm{L}_{\mathrm{VIII}}$ : Pacjentom, tak jest!

\section{WYPOWIEDZI LEKTORSKIE MOGĄCE OSLABIAĆ MOTYWACJĘ STUDENTÓW DO WYPOWIADANIA SIE NA ZAJĘCIACH}

Przeprowadzone analizy potwierdziły także wyniki badań prowadzonych w latach ubiegłych na gruncie dydaktyki ogólnej, zgodnie z którymi na osłabienie aktywności wśród studentów wpływają głównie: lęk przed krytyką i oceną, brak pewności siebie motywowany m.in. niedostateczną wiedzą, a także dominująca, działająca deprymująco rola lektora (zgodnie z regułą Flandersa wypowiedzi nauczycieli zajmują większość czasu lekcyjnego poświęconego na mówienie; Mądry-Kupiec 2011, s. 31) i jego sposób prowadzenia zajęć. W rezultacie uczniowie nie są dopuszczeni do głosu, a ich rola na lekcji ogranicza się do odtwarzania poznanego materiału w chwili wywołania do odpowiedzi. Konsekwencją tego jest trwanie uczących się w bierności.

Przedstawioną tezę zdaje się potwierdzać poniższy przykład, w którym po omówieniu wybranego tekstu prowadzący, nie czekając na opinie i wnioski uczestników zajęć, samodzielnie dokonał interpretacji i podsumowania wiadomości pozyskanych na kolejnych etapach pracy z materiałem dydaktycznym, np.:

[50] $\mathrm{L}_{\mathrm{I}}$ : Możemy przyjąć taką interpretację? Nikt wam nie narzuca zdania zupełnie, ale jest to chyba jedna z możliwych, prawda?

Ponadto, przykład ten ilustruje całkowite zatrzymanie możliwej do zaistnienia dyskusji. Wydaje się, że lektor podświadomie stanął w obronie swojej wypowie- 
dzi, asekurująco tłumacząc się z narzuconej interpretacji. Niefortunną wypowiedź zamyka pytanie o potwierdzenie: ,prawda?”, kończące wszelkie dalsze wywody i wymuszające na słuchaczach wyrażenie zgody.

$\mathrm{Z}$ drugiej strony podjęcie próby przejęcia przez ucznia roli mówcy, nie daje żadnej gwarancji na powodzenie komunikacji, np.:

[51] $\mathrm{L}_{\mathrm{x}}$ : Nie mówimy: Ona pracuje thumaczką, mówimy: Ona pracuje jako... To jest przetłumaczone z angielskiego. Ona...pracuje...pracuje...jako, plus mianownik, czyli jako tłu-macz$-\mathrm{ka}$, , a" to jest. Albo ona jest...

S: Tłumaczy książki!

$\mathrm{L}_{\mathrm{X}}$ : Nie Abel, powiedzieliście, że to nieprawda, ponieważ to, że ona jest tłumaczką, nie znaczy, że ona tłumaczy tylko książki. Być może, ale thumaczy różne inne rzeczy. Aha, czyli ona jest tłumaczką, ona zna trzy języki obce.

W powyższym przykładzie lektor, ignorując starania rozmówców, dość kategorycznie odrzuca propozycję ucznia, a następnie peroruje na temat właściwej odpowiedzi. Zamyka tym samym proces komunikacji zamiast otwierać go na nowych uczestników dyskursu.

Podobny, negatywny w skutkach efekt, został osiągnięty, gdy nauczyciel upominał studentów próbujących mówić jednocześnie. W konsekwencji wszyscy milkli, co zaburzało lub też całkowicie przerywało ciągłość komunikacji, np.:

[52] $\mathrm{L}_{\mathrm{x}}$ : O przypadkowych spotkaniach, ponieważ to nie jedno było, prawda? No dobrze, o przypadkowych spotkaniach, ale kto tam, o kim to...

S1: Między....między...

S2: między...

[mówia wszyscy na raz]

$\mathrm{L}_{\mathrm{X}}$ : Moment! Zaraz! Będzie twój moment!

Kolejnym krokiem w stronę demotywowania słuchaczy oraz dezintegracji komunikacji i samego procesu nauczania, było również wskazanie konkretnej osoby, mającej przejąć rolę mówcy. Rola ta była jednak w sposób kategoryczny narzucona, nie wynikała z naturalnej chęci czy potrzeby konwersacji, np.:

[53] $\mathrm{L}_{\mathrm{X}}$ : Pierwszy raz spotkali się $\mathrm{w}$ restauracji. Co potem?

S1: Już po raz drugi...

S2: potem...

$\mathrm{L}_{\mathrm{X}}$ : No, kolega bardzo chce ci pomagać, on bardzo chce mówić, słuchamy!

$\mathrm{S} 1:$ [śmiech]

S2: Yyy...Drugi rok, oni spotkają, spotkają...muzeum...

$\mathrm{L}_{\mathrm{x}}$ : Czyli spotkali się w muzeum w Polsce?

S2: Za granicą.

$\mathrm{L}_{\mathrm{x}}$ : Za granicą. I co tam, i co było dalej? Chciałeś mówić, słucham (A). Spotkali się w muzeum... 
Choć rozmówca początkowo chętnie zabierał głos w dyskusji, uzupełniając wystąpienie kolegi, wywołany do odpowiedzi, stracił pewność siebie, a tym samym chęć do swobodnego wyrażania myśli (fragment A).

Oprócz lektora również inni uczestnicy dyskursu mogą negatywnie wpływać na chęć wypowiadania się pozostałych uczniów, szczególnie, gdy ignorują osoby mówiące, same chcąc odpowiedzieć na zadane pytanie. Wiele wówczas zależy od podejścia pedagogicznego nauczyciela, który może cierpliwie oczekiwać odpowiedzi od pierwotnie wskazanego studenta lub też może ulec osobom o lepszej kompetencji komunikacyjnej i to z nimi prowadzić dalszy dialog, jak miało to miejsce w poniższej rozmowie:

[54] $\mathrm{L}_{\mathrm{x}}$ : Mhm, dobrze. Tak spotkali się po raz drugi. (...) wiem, że ty rozumiesz (A). Anas, co było dalej?

S: Spoty-emmm... spoty-spotykał Barbara i eee...krótkie...przed Krakowem...

Dodatkowo, na osłabienie motywacji do udzielenia poprawnej odpowiedzi mógł wpłynąć komentarz lektora skierowany do lepszego ucznia (fragment A). Wypowiedź ta miała również charakter oceniający, co stanowiło kolejną barierę motywacyjną dla uczących się. Wielu studentów odczuwa naturalny lęk przed oceną, stosują więc strategię uniku, w myśl której brak odpowiedzi jest równoznaczny z brakiem oceny. Dydaktycy, znając i dobrze rozumiejąc potrzeby uczniów, traktują system oceniania jako narzędzie wspierające rozwój kompetencji uczestników zajęć, a nie jako punkt odniesienia na skali zrealizowanych przez uczniów poleceń i zadań (Zawadzka 2004, s. 266-271; por. Janicka 2014).

Negatywny wpływ na płynność procesu komunikacyjnego miały także wypowiedzi o zabarwieniu emocjonalnym, które przybierały postać wykrzyknień, pozbawionych elementu wartościującego: wyrazów-sygnatów, np.:

[55] $\mathrm{L}_{\mathrm{II}}$ : Stop, stop, stooop! A eeee....Nuria, gdybyście wy, mówisz do koleżanek, nie Nuria, tylko wy...

[56] $\mathrm{L}_{\mathrm{x}}$ : Moment! (...) Chwileczkę!

[57] $\mathrm{L}_{\mathrm{xI}}$ : Stop, stop, stop! Spokojnie, spokojnie! Centralne Muzeum Włókiennictwa to jest Biała Fabryka.

Przenosiły one obszar zainteresowania z osoby mówiącej na lektora i na jego wypowiedzi koncentrowały uwagę słuchaczy. Nauczyciele stosowali wykrzyknienia przede wszystkim po to, aby szybko i skutecznie powstrzymać rozmówcę od dalszej wypowiedzi, a następnie, aby przejść do objaśnienia kwestii problematycznej.

Badacze zauważają ponadto, iż ,na odbiór przez uczniów informacji dezintegrująco wpływają różne wtręty językowe w wypowiedziach nauczycieli, takie jak: po prostu, właśnie, prawda, no nie" (Synowiec 1996, s. 206). W nagraniach również nie brak jest egzemplifikacji tego typu. Do najczęstszych należą: Tak? Prawda? Prosze państwa. 
Zaprezentowany w niniejszym artykule rejestr wypowiedzi werbalnych lektorów uczących JPJO wyraźnie ilustruje, że sytuacje komunikacyjne na lekcji znacząco różnią się od komunikacji przebiegającej w warunkach naturalnych. Zintensyfikowanie stosowania przez nauczycieli wypowiedzeń $\mathrm{w}$ funkcji aktywizującej czy fatycznej, ich dobór i sposób użycia są charakterystyczne wyłącznie dla przestrzeni szkolnej lub akademickiej. Co więcej, wypowiedzi te determinują udział w rozmowie wyłącznie jednego uczestnika układu komunikacyjnego. Są niejako przypisane a priori lektorowi, który wypowiada je świadomie i intencjonalnie: decyduje o tym, kto i kiedy ma zabrać głos na zajęciach, ile czasu i na jaki temat może się wypowiadać, a także o tym, kogo z rozmowy wykluczyć. Nauczyciel, poprzez wspomniane wypowiedzenia, zakłada nie tylko odbiór informacji przez studenta (lub zbiorowość), lecz także wykonanie konkretnej czynności. Jest to zatem układ jednokierunkowy, w którym prowadzący lekcję oczekuje określonej reakcji słuchacza, nigdy odwrotnie. Jednocześnie, jak pokazują przytoczone w artykule przykłady, lektorzy, poprzez swobodny styl prowadzenia zajęć i używanie języka w odmianie nie tylko ogólnej, ale i potocznej, próbują skompensować nierównorzędność ról nauczyciel-student (zob. Zawadzka 2004, s. 83).

Wydaje się jednak, że swoboda w kontaktach ze studentami jest w dużej mierze uzależniona od poziomu zaawansowania grupy, ale również od predyspozycji i cech personalnych nauczyciela, stąd przykłady niekiedy skrajnych zachowań lektorów: od familiarnych po autorytarne. Warto nadmienić, że wspomniana zażyłość prowadzących w kontaktach z podopiecznymi nie była uzależniona od wieku czy stażu pracy. Co ciekawe, w bezpośrednich zwrotach do słuchaczy ci sami lektorzy używali zarówno zwrotów bezpośrednich zawierających wyłącznie imię, jak i zwrotów formalnych uwzględniających formy grzecznościowe: pan/pani/państwo. Zjawisko to można wytłumaczyć, koncentrując się na kontekście aktu komunikacji, w szczególności na odbiorcach, którymi są osoby pełnoletnie, choć zazwyczaj poniżej dwudziestego roku życia, a także na miejscu - uniwersytecie, gdzie miały miejsce zajęcia JPJO. Biorąc pod uwagę wspomniane uwarunkowania oraz silnie przenikające ze znanego studentom języka angielskiego formy bezpośrednie występujące w kontaktach formalnych i nieformalnych, można wnioskować, iż zajęcia JPJO prowadzone dla osób młodych, uczących się w grupach wielonarodowościowych, pozostają miejscem nakładania się na siebie różnych odmian języka: oficjalnego i potocznego, formalnego i nieformalnego, a także funkcji językowych: referencyjnej, konatywnej, fatycznej i metajęzykowej, co zdecydowanie wyróżnia lekcję JPJO od innych zajęć dydaktycznych.

Omówione w artykule przykłady pokazały także, że istnieje wiele interesujących metod i technik, które są stosowane przez nauczycieli w celu nawiązania, podtrzymania kontaktu, a także wpłynięcia na emocje uczących się oraz nakłonienia ich „do podjęcia wysiłku, przekonując, że to nie jest trudne lub wskazując na 
praktyczny aspekt działania" (Nocoń 1996, s. 262). Z drugiej strony uwidoczniły one pewne nieświadome działania werbalne nauczycieli, które z założenia nastawione były na przerwanie procesu komunikacyjnego w celu dokonania korekty czy wskazania błędnego toku rozumowania studenta, a także na krytykę i ocenę wypowiedzi uczących się. Należy podkreślić, iż działania te nie zawsze były konieczne i zasadne, a niekiedy wynikały z wyraźnego zmęczenia lub zdenerwowania lektora zaistniałą sytuacją. Dlatego też celem pośrednim artykułu, obok opisu i próby sklasyfikowania zachowań werbalnych lektora, była również chęć skłonienia obecnych oraz przyszłych nauczycieli JPJO do autorefleksji nad własnymi wypowiedziami i ich wpływem na proces komunikacyjny i dydaktyczny.

Przytoczone analizy zgromadzonych przykładów z pewnością nie wyczerpują szerokiego tematu, jakim jest wpływ wypowiedzi lektora na motywację i aktywizowanie studentów do świadomego i czynnego udziału w lekcji JPJO. Warto wspomnieć także o innych sytuacjach komunikacyjnych, które nie zostały omówione w niniejszym artykule, takich jak: sposoby pozytywnego reagowania na wypowiedź ucznia, osłabianie i redukowanie dystansu pomiędzy lektorem i studentami, odwoływanie się do języka rodzimego słuchaczy czy tworzenie wspólnoty doświadczeń. Ich nagromadzenie i wielokrotna powtarzalność w czasie jednej lekcji JPJO, świadczą jedynie o bogactwie wypowiedzi lektorskich i, w konsekwencji, o konieczności dalszych badań ukierunkowanych na komunikację na lekcji.

\section{BIBLIOGRAFIA}

Janicka M., 2014, Pakiet metodyczny dla nauczycieli języków obcych I etapu edukacyjnego, Warszawa.

Komorowska H., 2001, Metodyka nauczania języków obcych, Warszawa.

Mądry-Kupiec M., 2011, Komunikacja werbalna nauczyciela i ucznia na lekcji, Kraków.

Nocoń J., 1996, Podręcznik w komunikacji dydaktycznej, w: T. Rittel (red.), Dyskurs edukacyjny, Kraków, s. 257-264.

Rachwałowa M., 1996, Formy adresatywne w literackim dyskursie szkolnym, w: T. Rittel (red.), Dyskurs edukacyjny, Kraków, s. 131-138.

Synowiec H., 1996, Kultura języka nauczycieli w sytuacji lekcyjnej, w: T. Rittel (red.), Dyskurs edukacyjny, Kraków, s. 203-210.

Zawadzka E., 2004, Nauczyciel języków obcych w dobie przemian, Kraków.

Żydek-Bednarczuk U., 1994, Struktura tekstu rozmowy potocznej, Katowice. 


\title{
Kamila Kubacka
}

\section{INITIATING AND MAINTAINING CONTACT WITH STUDENTS ON THE POLISH AS A FOREIGN LANGUAGE LESSON}

Keywords: communication in the Polish language classroom, educational communication, discourse in foreign language classroom, Polish as a foreign language lesson, teaching Polish as a foreign language, initiating a contact with student, maintaining contact during the lesson

\begin{abstract}
The aim of the article is to present examples of verbal (oral) lectors' behaviors that were aimed at initiating contact with students, maintaining attention and activating the participants in the institutionalized space, also the impact of lectures' communicationon the quality and the way of teaching in a non-homogeneous group. The research material includes twelve 90-minute recordings (with transcripts) of a foreign language lessons conducted by 12 lecturers at the Polish Language Center for Foreigners in Łódź. The presented analysis of the statements of teachers of Polish as a foreign language allowed for the development of a register of typical, most common communication situations in which the teacher interacted with students, as well as the identification and systematization of recurring common elements forming communication patterns. The analysis is linguistic-glottodidactic, at the same time a small fragment of research on educational discourse in the language classroom carried out in 2010-2014 for the purposes of the doctoral dissertation.
\end{abstract}

